\title{
Height, mass, and body fat percentage as functions of bmi, gender and age for PSDA from the NHANES 1999-2004 data sets
}

\author{
Arthur Allen ${ }^{1 *}$, Xiaojiang $\mathrm{Xu}^{2}$ \\ From 15th International Conference on Environmental Ergonomics (ICEE XV) \\ Portsmouth, UK. 28 June - 3 July 2015
}

\section{Introduction}

The USARIEM Probability of Survival Decision Aid (PSDA ver 1.0) has gender, height, mass, and body fat percentage inputs [1], but not age, that are either 'User Defined' or categorized as Very High, High, Mean, Low, Very Low. The default values of height and mass are from CDC's National Health and Nutrition Examination Survey (NHANES) [2]; and body fat\% are from [3]. However, body fat\% is based upon a limited sample size of 665 men and women ages 17 to 65 [3]. The NHANES examines and interviews about 5000 persons each year from representative samples. Each participant is given a unique sequence number and is weighted based upon the portion of the US population that individual represents. The NHANES 1999-2004 data set included the use of Dual-Energy X-ray Absorptiometry (DXA) to measure total body fat \% for 11,103 males and 9,687 females age 8 to 85 . The total data set had 12,729 males and 13,430 females age 24 to 1019 months (2 -85 years) representing the US population.

\section{Methods}

The NHANES data sets were downloaded from http:// www.cdc.gov/nchs/nhanes.htm in SAS XPORT files and converted to Matlab files for analysis and display. The three 2-year data sets of Demographics, Body Measurements, and DXA were combined using the unique sequence numbers, non-respondents were eliminated, and the combined data set was separated by gender and then by age. The weights were combined according to NHANES instructions.

\section{Results}

\section{Discussion}

Analysis of the NHANES 1999-2004 data base was used to update the height, mass, and body fat \% in PSDA ver 1.2. Confidence limits were determined to provide results for Very High, High, Low and Very Low estimates of height, mass, and body fat $\%$.

Table 1 Height/Mass on Gender, Age (months) Height (mean) $=A+B($ Age $)+C\left(\right.$ Age $\left.^{2}\right)$ and Mass (mean) $=$ D + E(Age) $+F\left(\right.$ Age $\left.^{2}\right)$

\begin{tabular}{ccccccc}
\hline Gender/Age & A & B & C & D & E & F \\
\hline Male $<=200 \mathrm{mo}$ & 74.866 & 0.6045 & -0.0004281 & 10.834 & 0.070687 & 0.0013087 \\
\hline Male $=>200 \mathrm{mo}$ & 174.079 & 0.01441 & $-1.71739 \mathrm{e}-05$ & 63.057 & 0.08842 & $-7.307256 \mathrm{e}-05$ \\
\hline Female $<=200 \mathrm{mo}$ & 65.3569 & 0.83438 & -0.0016530 & 2.876 & 0.26357 & 0.000330611 \\
\hline Female $=>200 \mathrm{mo}$ & 159.873 & 0.01678 & $-1.97931 \mathrm{e}-05$ & 50.629 & 0.08937 & $-7.43095 \mathrm{e}-05$ \\
\hline
\end{tabular}

\footnotetext{
* Correspondence: Arthur.A.Allen@uscg.mil

'U.S. Coast Guard Office of Search and Rescue, 1 Chelsea Street, New

London, CT 06320, USA

Full list of author information is available at the end of the article
} 
Table 2 Body Fat \% on Gender, Age (months), BMI $\left(\mathrm{kg} \cdot \mathrm{m}^{-2}\right) \mathrm{BF} \%=\mathrm{G}+\mathrm{H}$ Age $\left.+\mathrm{J}[1-\exp (-\mathrm{BMI} / \mathrm{K}))\right]$

\begin{tabular}{ccccc}
\hline Gender/Age & $\mathbf{G}$ & $\mathbf{H}$ & $\mathbf{J}$ & $\mathbf{K}$ \\
\hline Male $<=240 \mathrm{mo}$ & 1.1718 & -0.1285 & 88.2678 & 29.5664 \\
\hline Male $>240 \mathrm{mo}$ & -27.0486 & 0.0080 & 72.3643 & 22.8774 \\
\hline Female $<=240 \mathrm{mo}$ & -9.8860 & -0.0211 & 73.8279 & 22.0326 \\
\hline Female $>240 \mathrm{mo}$ & -37.3765 & 0.0057 & 87.5662 & 14.4364
\end{tabular}

\section{Conclusion}

Using height, mass, body fat\% relationships weighted to the entire US population and including the effects of age are more appropriate for the U.S. Coast Guard's use of PSDA than the original PSDA equations for height, mass and body fat \% [1].

\section{Authors' details}

${ }^{1}$ U.S. Coast Guard Office of Search and Rescue, 1 Chelsea Street, New London, CT 06320, USA. ${ }^{2}$ U.S. Army Research Institute of Environmental Medicine, Natick, MA 01760, USA.

Published: 14 September 2015

\section{References}

1. Xu X, Amin M, Santee WR: Probability of survival decision aid (PSDA). Natick MA USARIEM, 2008 Report\# USARIEM , T08/05, ADA478415.

2. Fryer $C D$, Hirshc R, Ogden CL: Anthropometric reference data for children and adults: U.S. Population, 1999-2002. Advanced data from vital health statistics 2005, 361:411-426.

3. Gagon J, Leon AS, Rao DC, Skinner JS, Bouchard C, Wilmore JH: The effect of sex, age and race on estimating percentage body fat from body mass index; The Heritage family Study. International J of Obesity 2006, 26:786-796.

Cite this article as: Allen and $\mathrm{Xu}$ : Height, mass, and body fat percentage as functions of bmi, gender and age for PSDA from the NHANES 19992004 data sets. Extreme Physiology \& Medicine 2015 4(Suppl 1):A9.

Submit your next manuscript to BioMed Central and take full advantage of:

- Convenient online submission

- Thorough peer review

- No space constraints or color figure charges

- Immediate publication on acceptance

- Inclusion in PubMed, CAS, Scopus and Google Scholar

- Research which is freely available for redistribution

Submit your manuscript at www.biomedcentral.com/submit 